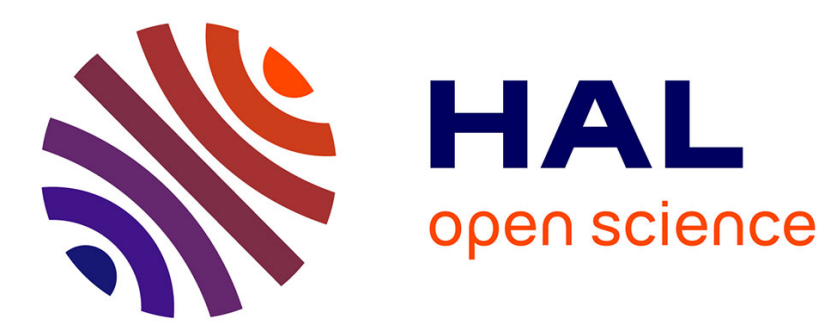

\title{
Hot Climate, Cold War
}

Matthias Dörries

\section{To cite this version:}

Matthias Dörries. Hot Climate, Cold War. Historical Studies in the Natural Sciences, 2020, 50 (1-2), pp.67-73. 10.1525/hsns.2020.50.1-2.67 . hal-02865769

\section{HAL Id: hal-02865769 \\ https://hal.science/hal-02865769}

Submitted on 18 Jun 2020

HAL is a multi-disciplinary open access archive for the deposit and dissemination of scientific research documents, whether they are published or not. The documents may come from teaching and research institutions in France or abroad, or from public or private research centers.
L'archive ouverte pluridisciplinaire $\mathbf{H A L}$, est destinée au dépôt et à la diffusion de documents scientifiques de niveau recherche, publiés ou non, émanant des établissements d'enseignement et de recherche français ou étrangers, des laboratoires publics ou privés. 
MATTHIAS DÖRRIES*

\section{Hot Climate Cold War}

BSTR CT

This essay is part of a special issue entitled "Looking Backward, Looking Forward: HSNS at 50," edited by Erika Lorraine Milam.

In 1997, Historical Studies in the Physical and Biological Sciences (HSPS) put "global warming" on the agenda for historians. An article by Spencer Weart deplored the complete absence of studies of the greenhouse effect and global warming written by historians of science. ${ }^{1}$ Indeed, aside from books on meteorology by Robert Marc Friedman, James R. Fleming, and Frederik Nebeker, historical studies of climate had been left exclusively to scientists and political scientists working in that field. ${ }^{2}$

Weart's article was not framed as a path-breaking historical study on climate change, but as an investigation into how "social factors such as funding and global politics" shaped research. It proposed an evolutionary model of scientific

**AHP-PReST, Université de Strasbourg, CNRS (French National Center for Scientific Research), USIAS (University of Strasbourg Institute for Advanced Study), Université de Lorraine, dorries@unistra.fr

The following abbreviations are used: HSNS, Historical Studies in the Natural Sciences; HSPS, Historical Studies in the Physical Sciences and Historical Studies in the Physical and Biological Sciences.

I. Spencer R. Weart, "Global Warming, Cold War, and the Evolution of Research Plans," HSPS 27, no. 2 (1997): 319-56, https://doi.org/10.2307/27757782.

2. Robert Marc Friedman, Appropriating the Weather: Vilhelm Bjerknes and the Construction of a Modern Meteorology (Ithaca, NY: Cornell University Press, 1989). Frederik Nebeker, Calculating the Weather: Meteorology in the 2oth Century, International Geophysics Series (San Diego: Academic Press, 1995). James R. Fleming, Meteorology in America, I800-1870 (Baltimore: John Hopkins University Press, 1990). James R. Fleming, Historical Perspectives on Climate Change (New York: Oxford University Press, 1998).

Historical Studies in the Natural Sciences, Vol. 50, Number I-2, pps. 67-73. ISSN 1939-18II, electronic ISSN 1939-182X. (c) 2020 by the Regents of the University of California. All rights reserved. Please direct all requests for permission to photocopy or reproduce article content through the University of California Press's Reprints and Permissions web page, https://www. ucpress.edu/journals/reprints-permissions. DOI: https://doi.org/I0.I525/hsns.2020.50.I-2.67. 
research, asking, "How did the timing and character of greenhouse-warming research plans in the 1950s relate to their social environment, shaped as it was by the Cold War?" 3 The article relied on archival research and fit into the general trend toward social studies that characterized the history of science during the 1990s. It also joined a rising number of historical studies on Cold War science, which, after the fall of the Berlin wall in 1989 , emerged in force. That same 1997 HSPS issue contained contributions by David A. Hounshell on the think tank, RAND, and by Daniel J. Kevles, who traced the death of the supercollider, itself a recent victim of the end of the Cold War. ${ }^{4}$

What then set Weart's article apart from others? Though not presented as such, Weart's article was of high political relevance. The very choice of topic, global warming, was at the center of an ongoing political debate about humanmade climate change: the second report of the Intergovernmental Panel on Climate Change had come out in 1995; the 1997 U.N. Framework Convention on Climate Change Kyoto conference was in preparation; and, more generally, newspapers and scientific journals with a wide audience, like Science and Nature, highlighted the topic of anthropogenic climate change and global warming throughout the 1990s. Weart made no direct reference to these debates, but alluded to them in the last lines, when he concluded that "the American government got a disturbing answer to a question that it had scarcely thought to ask." There was a "risk" of climate change, as Weart put it in another article at the same time published for an audience of physicists. ${ }^{6}$ Weart had originally been trained as a solar physicist at the University of Colorado, Boulder, and was familiar with the issue. ${ }^{7}$ In 1977, the scientific journal, Climatic Change, under the editorship of Stephen Schneider, had put the issue on the table, encouraging interdisciplinary exchange on the topic and also addressing policy issues. Twenty years later, Weart was the first historian of science to write a book on the history of global warming; he also started publishing a comprehensive, continuously updated website on global climate

3. Weart, "Global Warming" (ref. I), 319, 324.

4. David Hounshell, "The Cold War, RAND, and the Generation of Knowledge, I946I962," HSPS 27, no. 2 (1997): 237-67, https://doi.org/I0.2307/27757779. Daniel J. Kevles, “Big Science and Big Politics in the United States: Reflections on the Death of the SSC and the Life of the Human Genome Project," HSPS 27, no. 2 (1997): 269-97, https://doi.org/Io.2307/27757780.

5. Weart, "Global Warming" (ref. I), 356 (emphasis added).

6. Spencer R. Weart, “The Discovery of the Risk of Global Warming,” Physics Today 5o, no. I (2008): 34-40, on 34. https://doi.org/Io.Io63/I.88I664.

7. See Spencer R. Weart's interview: https://www.manhattanprojectvoices.org/oral-histories/ spencer-wearts-interview (accessed 2 Nov 2019). 
change at the American Institute of Physics (AIP). Weart's ultimate aim was public education, tuned to the globe's future. His study of the past was to inform upcoming political decisions. He wished to participate as a historian in the debate on climate change, where ultimately "hard decisions" would have to be made. ${ }^{8}$ His HSPS article was an invitation to other historians to engage with the issue of anthropogenic climate change.

Weart's article signaled a more general emergence in the history of science: historical studies in the geophysical sciences. Before the late 1990s, HSPS had published an occasional article on this topic, focusing on institutional history or conceptual change: Judith Goodstein on seismology at Caltech; Theodore S. Feldman on barometric hypsometry; Stephen G. Brush with an essay review entitled "Whole Earth"; John Servos, Gregory A. Good, and Lewis Pyenson writing on institutional history of geophysical institutes in the United States, Germany, China and Algeria; Naomi Oreskes on continental drift; and Eric L. Mills on oceanography. ${ }^{9}$ However, there was no community working on common themes. Things changed in the late 1990s. In 2000, HSPS published a special issue, edited by Barton C. Hacker, on "Military Patronage and the Geophysical Sciences in the United States." 10 The five articles, originally presented at the 1998 meeting of the American Geophysical Union (AGU) in Boston, concerned meteorology (James R. Fleming), geology (Martin L. Levitt), oceanography (Ronald Rainger and Naomi Oreskes), and geodesy (Deborah J. Warner). Groundwork for this development had

8. Spencer R. Weart, The Discovery of Global Warming (Cambridge, MA: Harvard University Press, 2003), viii.

9. Judith R. Goodstein, "Waves in the Earth: Seismology Comes to Southern California," HSPS I4, no. 2 (1984): 20I-30, https://doi.org/I0.2307/27757533; Theodore S. Feldman, "Applied Mathematics and the Quantification of Experimental Physics: The Example of Barometric Hypsometry," HSPS I5, no. 2 (1985): I27-95, https://doi.org/Io.2307/27757551; Stephen G. Brush, "Whole Earth History," HSPS I7, no. 2 (1987): 345-55, https://doi.org/10.2307/27757586; John W. Servos, "To Explore the Borderland: The Foundation of the Geophysical Laboratory of the Carnegie Institution of Washington," HSPS I4, no. I (1983): I47-85, https://doi.org/Io.2307/ 27757528; Gregory A. Good, "The Rockefeller Foundation, the Leipzig Geophysical Institute, and National Socialism in the 1930s," HSPS 2I, no. 2 (1991): 299-316, https://doi.org/I0.2307/ 27757665; Lewis Pyenson, "Habits of Mind: Geophysics at Shanghai and Algiers, 1920-1940," HSPS 2I, no. I (1990): I6I-96, https://doi.org/Io.2307/27757658; Naomi Oreskes, "The Rejection of Continental Drift," HSPS I8, no. 2 (1988): 3II-48, https://doi.org/Io.2307/27757605; Eric L. Mills, "Useful in Many Capacities. An Early Career in American Physical Oceanography," HSPS 20, no. 2 (1990): 265-3II, https://doi.org/I0.2307/27757645.

Io. Barton C. Hacker, ed., "Military Patronage and the Geophysical Sciences in the United States," HSPS 30, no. 2 (2000): 309-480. 
been laid by Gregory A. Good, who had published a comprehensive 900-page encyclopedia on the Sciences of the Earth, and by Ron Doel, who had worked with Spencer Weart at the AIP completing numerous interviews with (geo)physicists. ${ }^{11}$ James R. Fleming and Naomi Oreskes announced programmatically the emancipation of geophysics from the dominant discipline of physics in 2000:

Geophysics is in many ways like physics, and has often been considered a branch of it. Yet in its reliance on data collection from far-flung places and the recalcitrance of its phenomena to the discipline of the laboratory, it has more in common with geology. With its emphasis on whole Earth problems, it shares methodological and epistemological concerns with evolutionary biology. With its relevance to industrial problems, it has much in common with chemistry. Geophysics is not—and has never been—simply physics applied to the Earth. ${ }^{12}$

From its creation in 1969 as Historical Studies in the Physical Sciences, through the late 1990s, HSPS had been a powerhouse for the history of the physical sciences, under its two editors in chief, Russell McCormmach and John L. Heilbron. "Biology" sneaked into the title of the journal in the 1980s, but appeared only sporadically. However, from the I990s, the disciplinary boundaries started to loosen, as historians' objects of research became increasingly multifaceted, posing new social and political questions. This shift was further confirmed when HSPS became HSNS, Historical Studies in the Natural Sciences, under Cathryn Carson as chair in 2008. The new journal aimed for a "wider reach in the natural sciences and a broader methodological spectrum," and "a diversity of topics and approaches." 13

Articles in this journal during the first decade of the twenty-first century further developed two intellectual lines derived from the pioneering work on climate change and geophysics of the late 1990s: First, a 2006 special issue on Changing climate-Modeling climate, put the focus on climate and the whole

II. Gregory A. Good, ed., Sciences of the Earth: An Encyclopedia of Events, People, and Phenomena (New York: Garland, 1998). Ronald E. Doel, "The Earth Sciences and Geophysics," in Science in the Twentieth Century, ed. John Krige and Dominique Pestre (London: Harwood Academic Publishers, 1997), 36I-88.

I2. Naomi Oreskes and James R. Fleming, "Why Geophysics?," Studies in History and Philosophy of Modern Physics 3I (2000): 253-57, on 254-55.

I3. The Editors, "On Relaunching a Journal," HSNS 38, no. I (2008): I-3, on I. 
Earth. ${ }^{14}$ The issue addressed intended and unintended climate changes and their modeling from a variety of perspectives: weather modification and geoengineering (James R. Fleming), ecology (Christophe Masutti), climate modeling (Matthias Heymann), and volcanology (Matthias Dörries). It was part of a turn to global studies in the history of science, dealing with the (im)possibilities of earthly politics and environmental governance, and the delicate balance between the global and the local. Here, geophysics and climate studies played a primordial role, as in the books by Clark A. Miller and Paul N. Edwards (200I), Sheila Jasanoff and Marybeth Long Martello (2004), Iris Schröder and Sabine Höhler (2005), John Krige and Kai-Hendrik Barth (2006), and James R. Fleming, Vladimir Jankovic, and Deborah R. Coen (2006). ${ }^{15}$

Second, the journal became part of the fierce political discussion about global climate change in the United States. In 2007, Spencer Weart referred explicitly to the risks of global warming in his article on the funding of Keeling's measurements of carbon dioxide. He addressed the issue of the increasing "politicization of some scientific decisions," regretting "the unequalled rise to power in America of right-wing anti-intellectual anti-elite attitudes."16 Weart himself, by defending an ideal of disinterested scientific expertise, had now directly joined the political debate. For historians of science, working on climate change, there was no neutral ground. This posed new challenges and became obvious a year later with the inaugural issue of HSNS in 2008. The issue included an article by Naomi Oreskes, Erik M. Conway, and Matthew Shindell, which argued that the physicist William A. Nierenberg had deliberately changed the 1983 National Academy of Science's report on climate change, distorting an emerging consensus within the scientific

I4. Matthias Dörries and Christophe Masutti, eds. "Changing Climate-Modeling climate," HSPS 37, no. I (2006): I-I25.

I5. Clark A. Miller and Paul N. Edwards, eds. Changing the Atmosphere: Expert Knowledge and Environment Governance (Cambridge, MA: MIT Press, 20oI); Sheila Jasanoff and Marybeth Long Martello, Earthly Politics: Local and Global in Environmental Governance (Cambridge, MA.: MIT Press, 2004); Iris Schröder and Sabine Höhler, eds., Welt-Räume: Geschichte, Geographie and Globalisierung seit 1900 (Frankfurt: Campus, 2005); John Krige and Kai-Henrik Barth, eds., Global Power Knowledge: Science and Technology in International Affairs, Osiris 2I (2006); James R. Fleming, Vladimir Jankovic and Deborah R. Coen, eds., Intimate Universality: Local and Global Themes in the History of Weather and Climate (Sagamore Beach, MA: Science History Publications, 2006).

I6. Spencer R. Weart, "Money for Keeling: Monitoring $\mathrm{CO}_{2}$ Levels," HSPS 37 (2007): $435-52$, on 45 I. 
community. ${ }^{17}$ The 2008 article foreshadowed Oreskes and Conway's polemical and highly influential book of 2010, Merchants of Doubt: How a Handful of Scientists Obscured the Truth on Issues from Tobacco Smoke to Global Warming. This book showed that a group of prominent, conservative, and wellestablished physicists had manipulated scientific knowledge, casting doubt on the dangers of smoking, acid rain, and global climate change, in order to prevent or delay political action. The virulence and violence of the ensuing exchanges between the advocates of the opposing sides, a new Cold War, left little room for gray zones of argumentation or historical ambiguity. Family members of William A. Nierenberg contested the conclusions of the 2008 article, and published an alternative interpretation of Nierenberg's 1983 actions in HSNS. ${ }^{18}$ Historical debates about what was known when now joined the ongoing political debate over climate change. Historians faced the impossibility of defending a disinterested scientific position within the contemporaneous political context. Their narratives became "part of the struggle to control the telling of stories itself," as Joshua Howe observed in his review of Merchants of Doubt in $2012 .{ }^{19}$

I finish my survey in 20I0, when the situation became increasingly unübersichtlich (to borrow a term from Jürgen Habermas). A flood of historical publications on climate, environment, and geophysics had begun, a development reflected in HSNS not only in the articles it published, but also in a series of excellent review essays, a format introduced in 2008. After the first steps of the pioneers in the late 1990s, and consolidation and politicization of the field, a now-large transdisciplinary community began to critically take stock of what had been achieved and explore where things might be heading. In 20IO, Deborah Coen penned the first HSNS review essay on weather and climate, observing a cultural turn in climate studies. ${ }^{20}$ Subsequently, some ten review essays on books at the intersection of geophysics, environmental history, climate, geology, atmospheric studies, or globalization, have shown the

I7. Naomi Oreskes, Erik M. Conway, and Matthew Shindell, "From Chicken Little to Dr. Pangloss: William Nierenberg, Global Warming, and the Social Deconstruction of Scientific Knowledge," HSNS 38, no. I (2008): I09-52, https://doi.org/I0.I525/hsns.2008.38.I.I09.

I8. Nicolas Nierenberg, Walter R. Tschinkel, and Victoria J. Tschinkel, "Early Climate Change Consensus at the National Academy: The Origins and Making of Changing Climate," HSNS 40, no. 3 (2010): 318-49, https://doi.org/Io.1525/hsns.2010.40.3.318.

19. Joshua P. Howe, "The Stories We Tell," HSNS 42, no. 3 (2012): 244-54, on 246, https:// doi.org/IO.I525/hsns.20I2.42.3.244.

20. Deborah R. Coen, "Weatherwiser?," HSNS 40, no. I (2010): I25-35, https://doi.org/Io. I525/hsns.2010.40.I.I25. 
exciting diversity of the field. In parallel with the review essays, articles published in the last ten years have explored an array of topics and areas, including the International Geophysical Year, the uses of diagrams in environmental sciences, arctic exploration, space oceanography, and the history of climate studies and institutions outside the United States.

Where will HSNS venture in the future? I have no idea. A journal like HSNS is a collective undertaking, and reflects as much as shapes a whole research community. The editors may set priorities, but, in the end, they depend on submissions. It is likely that the question of climate will haunt us in the next decades, and that the recent past will come into increasing historical focus. New themes, approaches, and interpretations will join the larger political debate, just as Weart advocated over twenty years ago. 